\title{
Implementation of the blended learning model in the study of mathematical disciplines
}

\author{
Bilous 0.* \\ Sumy State University, Sumy, Ukraine
}

Received: 17.02 .2020

Accepted: 26.03 .2020

\begin{abstract}
The introduction of various information technologies into the learning process remains relevant. Higher schools are developing new forms and methods of teaching, focused on the use of computer Internet technologies. In the context of informatization of the education sector, the introduction of blended learning, as one of the varieties of e-learning, is best suited to the task of forming the cultural and professional competences of the future engineer. Blended learning technology has significant didactic capabilities and is characterized by a variety of forms, methods and learning tools provided, their interactivity, different ways of interaction between the subjects of the educational process and most fully meets the specifics of the university. The features of the use of distance learning technologies for students of the day department of engineering and technical specialties are considered in the article, the use of the basic elements of the e-course is described. Elements of electronic courses introduced in the educational process are presented, one form of blended learning is described. Within the course of higher mathematics, which is taught at Sumy State University, an information and practical block was formed. The information block is presented by electronic lecture notes with a built-in dictionary, video lectures and presentations. Information from the theoretical unit of the discipline is available to the student at any time when accessing through the student's personal office. Practical block of study of mathematical discipline includes tasks for individual work, simulators, tests. The article describes the peculiarities of implementation of these elements in the educational process. It is noted that the mixed approach to learning gives more interactivity and stimulates active learning, motivates students to educational and cognitive activity, allows to develop skills of independent learning, promotes the development of creative thinking and search for non-standard solutions. The introduction of electronic control elements of training (tests, tasks for joint performance, etc.) allows the teacher to get rid of the routine work of checking the intermediate learning result. Electronic systems allow you to do this quickly, efficiently, impartially. Conclusions have been made regarding the effectiveness of introducing blended learning into the learning process.
\end{abstract}

Key words: electronic training course, interactive classes, educational information technologies.

\section{Впровадження моделі змішаного навчання при вивченні математичних дисциплін}

\author{
Білоус 0. А. \\ Сумський державний університет, Суми, Україна
}

\begin{abstract}
Анотація. Впровадження різних інформаційних технологій в процес навчання продовжує бути актуальним. У вищій школі розробляються нові форми і методи навчання, орієнтовані на використання комп'ютерних та інтернет-технологій. В умовах інформатизації сфрери освіти, запровадження змішаного навчання, як одного 3 різновидів електронного навчання, найкращим чином відповідає завданню формування загальнокультурних і професійних компетентностей майбутнього інженера. Технологія змішаного навчання володіє значними дидактичними можливостями і характеризується різноманітністю представлених форм, методів і засобів навчання, їх інтерактивністю, різними способами взаємодії суб'єктів освітнього процесу. Вона найбільш повно відповідає специфіці вузу. У статті розглянуті особливості застосування технологій дистанційного навчання для студентів денного відділення інженерно-технічних спеціальностей, описано використання основних елементів електронного курсу. Наводяться елементи електронних курсів впроваджених в навчальний процес, описана одна з форм змішаного навчання. В рамках курсу вищої математики, який викладається в Сумському державному університеті, ссформований інформаційний та практичний блок. Інформаційний блок представлений електронними конспектами лекцій з вбудованим словником, відео лекціями та презентаціями.
\end{abstract}

Corresponding Author: Bilous Olena Anatolievna. E-mail: o.bilous@maimo.sumdu.edu.ua. Sumy State University, st. R.- Korsakov 2, Sumy, Ukraine, 40007.

Відповідальний автор: Білоус Олена Анатоліївна. E-mail: o.bilous@maimo.sumdu.edu.ua. Сумський державний університет, вул. Р.- Корсакова 2, м. Суми, Україна, 40007. 
Інформація теоретичного блоку дисципліни доступна студенту в будь який час при зверненні через особистий кабінет студента. Практичний блок вивчення математичної дисципліни включає в себе завдання для індивідуальної роботи, тренажери, тести. Робота в рамках практичного блоку проводиться згідно графіку вивчення дисципліни. В статті описуються особливості впровадження в навчальний процес відповідних електронних об'єктів навчання. Відзначено, що змішаний підхід до навчання дає більше інтерактивності і стимулює активне навчання, мотивує студентів до навчально-пізнавальної діяльності, дозволяє сформувати навички самостійного навчання, сприяє розвитку творчого мислення та пошуку нестандартних рішень. Впровадження електронних контролюючих елементів навчання (тестів, завдань для спільного виконання та ін.) дозволяє викладачу позбавитись рутинної роботи по перевірці проміжних результаті навчання. Електронні системи дозволяють це зробити швидко, якісно, неупереджено. Зроблені висновки щодо ефективності впровадження змішаної форми навчання в навчальний процес.

Ключові слова: електронний навчальний курс, інтерактивні заняття, навчальні інформаційні технології.

\title{
Внедрение модели смешанного обучения при изучении математических дисциплин
}

\author{
Белоус Е. А. \\ Сумский государственный университет, Сумы, Украина
}

\begin{abstract}
Аннотация. Внедрение различных информационных технологий в процесс обучения продолжает быть актуальным. В высшей школе разрабатываются новые формы и методы обучения ориентированные на использование компьютерных интернет-технологий. В условиях информматизации сфреры образования, введение смешанного обучения, как одной из разновидностей электронного обучения, наилучшим образом соответствует задаче формирования общекультурных и профессиональных компетенций будущего инженера. Технология смешанного обучения обладает значительными дидактическими возможностями и характеризуется разнообразием предоставляемых форм, методов и средств обучения, их интерактивностью, различными способами взаимодействия субъектов образовательного процесса и наиболее полно соответствует специфике вуза. В статье рассмотрены особенности применения технологий дистанционного обучения для студентов дневного отделения инженерно-технических специальностей, описано использование основных элементов электронного курса. Приводятся элементы электронных курсов внедренных в учебный процесс, описана одна из форм смешанного обучения. В рамках курса высшей математики, который преподается в Сумском государственном университете, сформирован информационный и практический блок. Информационный блок представлен электронными конспектами лекций со встроенным словарем, видео лекциями и презентациями. Информация из теоретического блока дисциплины доступна студенту в любое время при обращении через личный кабинет студента. Практический блок изучения математической дисциплины включает в себя задачу для индивидуальной работы, тренажеры, тесты. В статье описываются особенности внедрения в учебный процесс этих элементов. Отмечено, что смешанный подход к обучению дает больше интерактивности и стимулирует активное обучение, мотивирует студентов к учебно-познавательной деятельности, позволяет ссрормировать навыки самостоятельного обучения, способствует развитию творческого мышления и поиска нестандартных решений. Внедрение электронных контролирующих элементов обучения (тестов, задач для совместного выполнения и др.) позволяет преподавателю избавиться от рутинной работы по проверке промежуточных результатов обучения. Электронные системы позволяют это сделать быстро, качественно, беспристрастно. В статье сделаны выводы об эфффективности внедрения смешанной формы обучения в учебный процесс.
\end{abstract}

Ключевые слова: электронный учебный курс, интерактивные занятия, учебные инфоормационные технологии.

\section{Bcmyn}

Сучасний етап розвитку суспільства характеризується активним впровадженням засобів нових інформаційних технологій в усі сфери людської діяльності. Стрімкі темпи розвитку технічних засобів і програмного забезпечення вимагають відповідних темпів модернізації всіх компонентів системи навчання. Однією з проблем освіти справедливо вважають протиріччя між характером професійної діяльності сучасного інженера в умовах все більш зростаючого обсягу інформації, інтенсивного впровадження і використання засобів інформаційних і комунікаційних технологій, і традиційним рівнем навчання [1-3]. Сучасні тенденції розвитку професійної освіти, пов'язані з введенням нових державних освітніх стандартів, інфрорматизацією сфери освіти, переорієнтацією технологій навчання на самостійну дослідницьку роботу, вказують на те, що вдосконалення системи професійної підготовки майбутніх 
фахівців неможливо без впровадження нових технологій навчання, Інтернету, e-learning, систем управління навчанням, а також без підвищення рівня розвитку професійних якостей фахівця, як необхідній передумови компетентності випускника інженерних вузів [4-6].

3 усіх різновидів e-learning особливу роль набуває змішане навчання, яке має для сучасного розвитку як системи освіти в цілому, так і локального навчального процесу хороші перспективи. Останнім часом посилений інтерес до проблеми змішаного навчання пояснюється активним використанням інформаційних технологій в навчальному процесі, оскільки дистанційне навчання реалізується в наші дні, перш за все, специфічними засобами інтернет-технологій або іншими засобами, які передбачають інтерактивність $[7,8]$. Іншими словами, змішане навчання (blended learning) розуміється в наші дні як поєднання традиційної форми навчання «обличчям до обличчя» (face-to-face instruction) і електронного навчання (e-learning), що характеризується використанням інформаційних, електронних технологій, тобто істотно спирається на допомогу комп'ютера (computer-mediated instruction) $[9,10]$. Найважливішою (але не єдиною) формою електронного навчання $є$ інтернетнавчання, що передбачає доставку навчального контенту за допомогою мережі Інтернет. У свою чергу, найбільшого поширення в інтернет-навчанні отримало використання засобів, які передбачають спілкування в онлайн-режимі, тобто онлайн-навчання [11].

Таким чином, змішане навчання (гібридне навчання, порційне навчання) може бути визначено як освітня технологія, інтегруюча традиційне навчання за участю педагога і он-лайн-навчання [12, 13]. Це дозволяє використовувати всі переваги електронного навчання, не втрачаючи при цьому сильних сторін навчання «живого». Слід зауважити, що суть змішаного навчання полягає не в тому, що частина освітнього процесу реалізовується он-лайн, а в тому, що студент отримує можливість вибору і контролю термінів, ходу, темпу і місця свого навчання, може самостійно вирішувати, як, коли, де і з якою швидкістю йому вчитися [14].

Одним 3 нових підходів у викладі фундаментальних дисциплін $є$ впровадження змішаного навчання, роль якого полягає в комплексному поєднанні електронного (дистанційного) навчання і традиційних аудиторних занять [15]. Змішана модель навчання надає студентам нові можливості по вивченню дисциплін, оскільки можна не тільки в будь-який час переглянути необхідний матеріал в режимі он-лайн, але і пройти тестування, перевірити свої знання з окремої теми або предмету в цілому, ознайомитися з додатковими джерелами, які точно відповідають пройденим темам. Таким чином, для математичних дисциплін виникає необхідність раціонального поєднання компонентів традиційного і дистанційного навчання для їх ефективної взаємодії в процесі навчання.

Актуальність дослідження підтверджує той фракт, що більшість активних педагогів [13-15] не можуть більше працювати в умовах зростаючого протистояння між широкими можливостями інформаційно- комунікаційних технологій в сфері освіти і обмеженнями аудиторної моделі організації навчання. Тому виникає питання пошуку розумної та ефективної альтернативи традиційним і явно застарілим способам організації навчання у вищих навчальних закладах.

Метою стаmmi є аналіз можливостей і ефективності застосування електронного математичного дистанційного курсу, паралельно з традиційним викладанням матеріалу для студентів денного відділення спеціальностей фізико-технічного спрямування. Крім того, досліджується впровадження елементів змішаної форми навчання для окремо взятого математичного курсу, а також виділення основного набору компонентів електронного курсу, які найкращим чином доповнюють традиційне навчання. Метою даної роботи є обговорення результатів нашого досвіду використання можливостей blearning в рамках навчального процесу з математики.

\section{II Матеріал і методи дослідження}

У ході дослідження проведений аналіз вітчизняних і зарубіжних публікацій, що відносяться до теми дослідження, спеціальної методичної літератури, присвяченої питанням ефективності різних моделей навчання, інновацій в навчанні у вищій школі, застосування дистанційних курсів, побудови та організації моделі змішаного навчання. До практичних методів дослідження відносяться: впровадження електронного курсу; комбінування навчання в аудиторії з навчанням за допомогою засобів Інтернету; опитування та анкетування студентів-слухачів курсу; порівняльний аналіз успішності групи, студенти якої були підключені до електронного курсу, і групи того ж потоку, студенти якої до не були підключені. 
При розробці електронного курсу, призначеного для використання в рамках змішаної форми навчання, особливу роль відіграє оптимальний вибір дидактичних засобів навчання, під якими ми розуміємо об'єкти, створені людиною, і предмети, які використовуються в освітньому процесі в якості носіїв навчальної інформації та інструментів діяльності. Саме такі засоби навчання відносимо до матеріалів дослідження.

\section{III Результати}

Змішана модель навчання надає студентам нові можливості по вивченню дисциплін, оскільки можна не тільки в будь-який час переглянути необхідний матеріал в режимі он-лайн, але і пройти тестування, перевірити свої знання з окремої теми або предмету в цілому, ознайомитися з додатковими джерелами, які точно відповідають пройденим темам. Таким чином, для математичних дисциплін виникає необхідність раціонального поєднання компонентів традиційного і дистанційного навчання для їх ефективної взаємодії в процесі навчання.

В Сумському державному університеті курс вищої математики для студентів інженерно-фізичного напряму підготовки (6.171 - Електроніка, 6.141 - Електроенергетика, електротехніка та електромеханіка, 6.172 - Телекомунікації та радіотехніка, 6.151 - Автоматизація та комп'ютерноінтегровані технології, 6.153 - Мікро- та наносистемна техніка) традиційно читається на першому курсі протягом двох семестрів (дивись таблицю 1).

Табл. 1. Характеристика навчальної дисципліни «Вища математика»

\begin{tabular}{|c|c|c|c|c|c|c|c|c|c|c|}
\hline \multirow{2}{*}{$\begin{array}{c}\text { Семестр } \\
\text { викладання }\end{array}$} & \multirow{2}{*}{$\begin{array}{c}\text { Загальний } \\
\text { обсяг, } \\
\text { годин/кред. }\end{array}$} & \multicolumn{6}{|c|}{ Навчальна робота за семестр, годин } & \multicolumn{2}{|c|}{ СРС, годин } & \multirow{2}{*}{$\begin{array}{l}\text { Форма } \\
\text { контр. }\end{array}$} \\
\hline & & Всього & лекції & Практ. & Лаб. & КзP & A & Загалом & Інд. зав & \\
\hline 1 & $300 / 10,0$ & 128 & 48 & 80 & - & 8 & 4 & 172 & - & ДСК \\
\hline 2 & $300 / 10,0$ & 112 & 40 & 72 & - & 8 & 4 & 188 & - & ДСК \\
\hline
\end{tabular}

Слід відзначити, що з 600 годин загального обсягу дисципліни тільки 240 годин проводяться у якості аудиторних занять, в той час як більша половина годин виноситься на самостійне опрацювання матеріалу дисципліни. Тому, спроба побудови електронного курсу з цієї дисципліни, і організація на його основі навчального процесу з використанням елементів дистанційного навчання (з поступовим переходом до інтеграції традиційного очного і дистанційного навчання) $є$ актуальною та такою, що відповідає вимогам сучасності.

Мета викладання курсу - формування особистості студентів, розвиток інтелекту, логічного та алгоритмічного мислення, навчання основним методам, навичкам і прийомам побудови математичних моделей, а також методам аналізу складних задач. Вироблення твердих навичок дослідження та розв'язання певного кола задач, що мають як посереднє, та і безпосереднє відношення до відповідної спеціальності.

3 метою реалізації відповідних задач з підготовки студентів, розроблений и вже декілька років застосовується електронний навчальний курс з вищої математики. Навчання за цим курсом ведеться паралельно з традиційним викладом матеріалу в аудиторії для студентів денної форми навчання. Він розміщений на платформі змішаного навчання СумДУ за адресою https://mix.sumdu.edu.ua (рис. 1). Презентація платформи змішаного навчання СумДУ знаходиться за адресою https://issuu.com/yuriyzuban/docs/mix_sumdu.

Створення електронного курсу вищої математики переслідує кілька цілей, зокрема, мотивувати всіх студентів до більш глибокого вивчення фундаментальної дисципліни, зацікавити успішних студентів у вивченні окремих додаткових розділів, зорієнтувати і направити тих студентів, які бажають вивчати курс самостійно. Слід зазначити, що кожному студенту університету сформований особистий кабінет в якому наявна можливість авторизованого підключення до курсів, які представлені студентам відповідного року навчання. Студенти із зацікавленістю сприймають підключення до електронного курсу, а статистика відвідувань свідчить, що кожен слухач курсу підключається он-лайн не тільки для 
відправки модульних завдань, а й для перегляду та участі на інших сторінках курсу, і в середньому знаходиться он-лайн не менше 1,5 годин в тиждень.

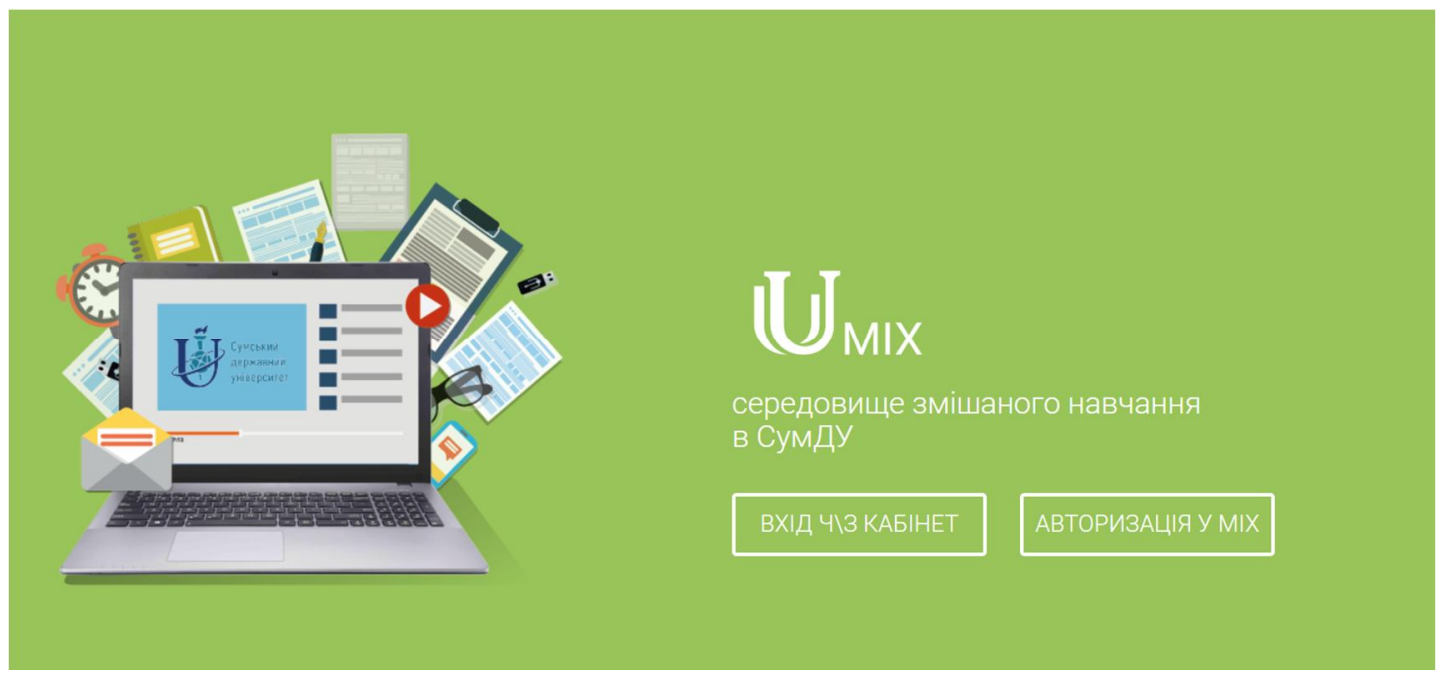

Рис. 1. Платформа змішаного навчання СумДУ

Одночасно із студентами, у викладача дисципліни сформована можливість супроводження електронної частини навчання студентів (рис. 2).

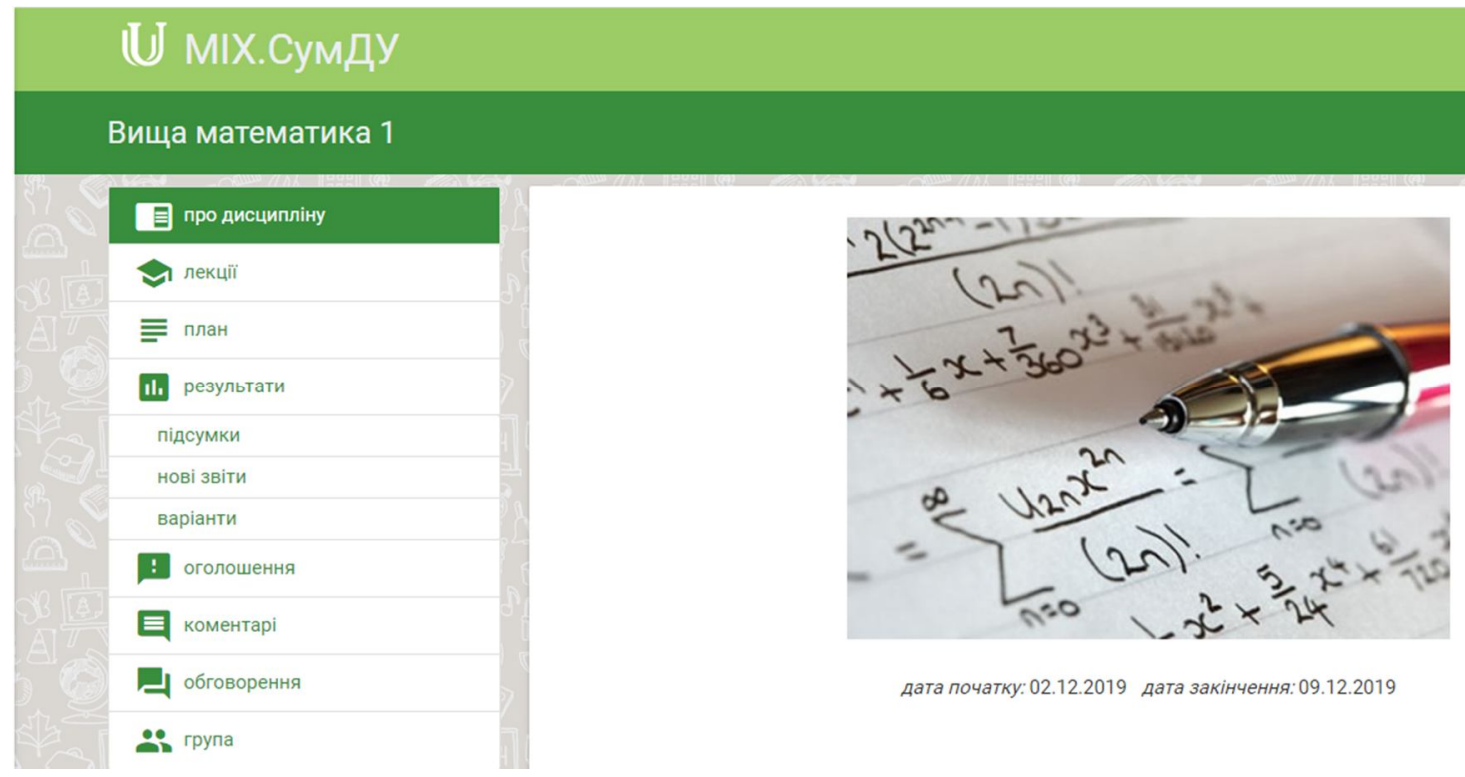

Рис. 2. Інформаційне вікно викладача

Розроблений електронний курс відповідає робочій програмі дисципліни, відповідає всім основним вимогам, що пред'являються до електронних курсів [10].

Курс складається із інформаційного та практичного блоків. Так, інформаційний блок (рис. 3), представлений у вигляді текстових та відео лекцій, презентацій. Вони у будь який час $є$ доступними для студентів, що вивчають цей матеріал.

Практична частина курсу складається з завдань для самостійної роботи, тестових завдань, тренажерів.

Календар електронного курсу налаштований окремо, включена розсилка повідомлень про зміни в курсі. Перший форум створений для обговорення організаційних питань по курсу, обговорення стандартних завдань, і налаштований так, що кожен учасник бачить відповіді всіх інших учасників форуму. Другий форум створений для обговорення завдань підвищеної складності, вправ і питань, які 
виникали додатково під час лекції. Цей форум налаштований в режимі «Питання - відповідь». Викладач бачить відповіді всіх учасників, а кожен учасник може побачити все обговорення, що відбувається в темі, тільки після того, як відповість сам. Чат запланований у вигляді он-лайн консультації один раз на тиждень в будній день ввечері, проте слід зауважити, що оскільки по курсу передбачалися традиційні аудиторні консультації, то чат був затребуваний мало.

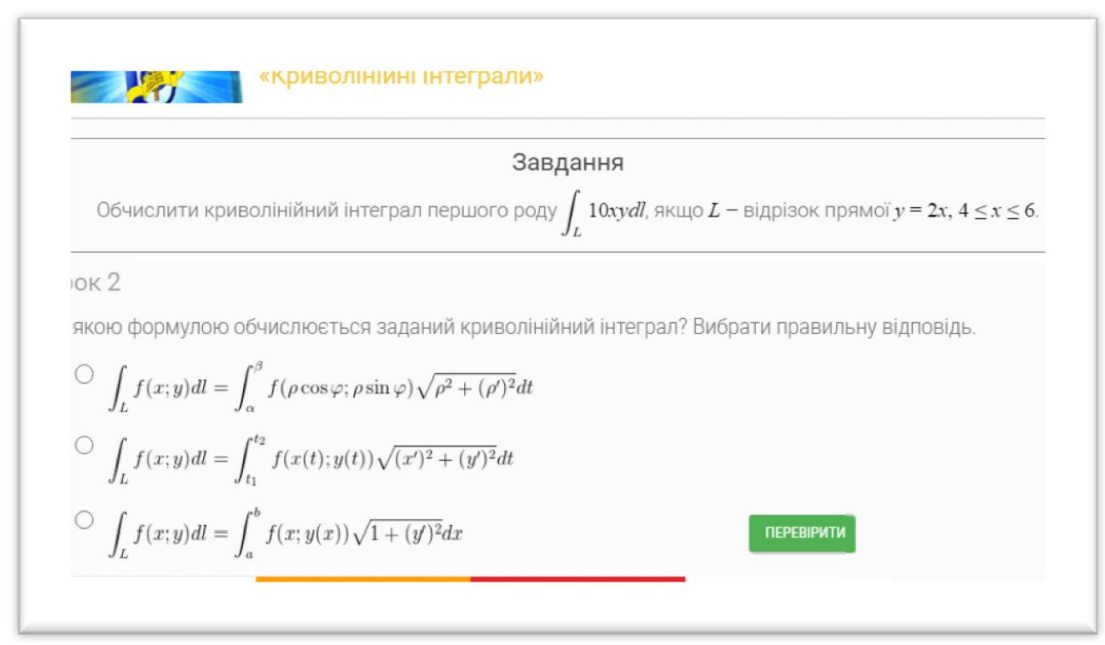

Рис. 3. Вікно тренажера за темою «Криволінійні інтеграли»

Словник - традиційна складова будь-якого дистанційного курсу, на момент підключення слухачів до курсу містив необхідний мінімум термінів, далі студенти наповнювали його в міру вивчення курсу.

Одним з дидактичних завдань підключення до електронного курсу $є$ оцінювання досягнень студентів. Налаштування курсу дозволяють візуалізувати отримані результати і оцінки при виконанні студентом тестів і домашніх завдань, що зручно і студенту, і викладачеві. Таке оцінювання зручно виконати за допомогою тренажерів. В цих системах студент покрокового виконує завдання з відповідної теми. Для кожного кроку проводиться проміжний автоматичний контроль з можливістю повернення на попередній етап роботи з тренажером.

Тренажери дозволяють студентам в будь-який момент самостійно вдосконалювати навички рішення задач за даними розділами. У кожному такому тренажері підібрані найтиповіші завдання даного розділу математики. Вони структуровані за рівнями складності і передбачають декілька кроків у своєму виконанні (рис. 3).

Ще однією перевагою тренажерів $€$ те, що вирішуючи завдання студент відразу бачить на якому етапі роботи їм була допущена помилка. Тому він може, виправивши помилку, продовжити рішення вірно. Це важливо, оскільки при вирішенні завдання традиційним способом, якщо студент припустився помилки в першій дії, то далі буде йти невірне рішення. У кращому випадку він зрозуміє, що припустився помилки тільки тоді, коли отримає неправильну відповідь, але йому не буде показано в якому саме місці він припустився помилки (рис. 4). У тренажері перевірка здійснюється після виконання кожної дії, при цьому неправильно виконана дія виділяється червоною рамкою. Тільки після того, як помилка буде виправлена, тренажер перевірить правильність виконання наступних дій. Таким чином, за допомогою цих тренажерів студенти не тільки підвищують свою математичну культуру, а й мають можливість здійснювати самоконтроль. Наприклад, напередодні написання контрольної роботи або складання іспиту студент може сам перевірити, за допомогою тренажера, наскільки вірно він виконує ті чи інші завдання. Цільовий характер описаного тренажера пов'язаний з формуванням первинних знань і рахункових навичок, а також закріпленням вивченого матеріалу студентами за відповідними темами.

Відзначимо також, що дані тренажери можуть використовуватися як окремо, так і спільно 3 інтерактивними практикумами, в залежності від кількості наявного часу на вивчення предмета, оснащеності комп'ютерами аудиторій, рівня підготовки студентів і очікуваного результату навчання. 


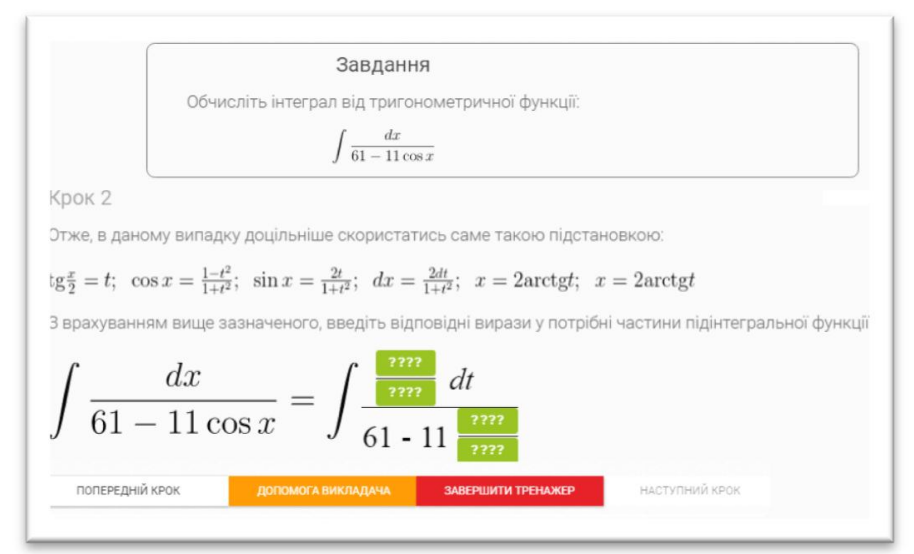

Рис. 4. Вікно тренажера на другому кроці його виконання за темою «Невизначений інтеграл»

Крім тренажерів контролюючу функцію при вивченні дисципліни мають тести різного рівня складності, приклад наведено на рисунку 5. Слід зазначити також, що під час проходження тесту в процесі навчання студент має змогу користуватися як лекцією, так і інтернет-ресурсами. Причому цей фракт не розцінюється як недолік форми навчання, оскільки шукаючи відповіді на поставлені питаннязадачі студент заповнює прогалини своїх знань і таким чином готується до складання іспиту.

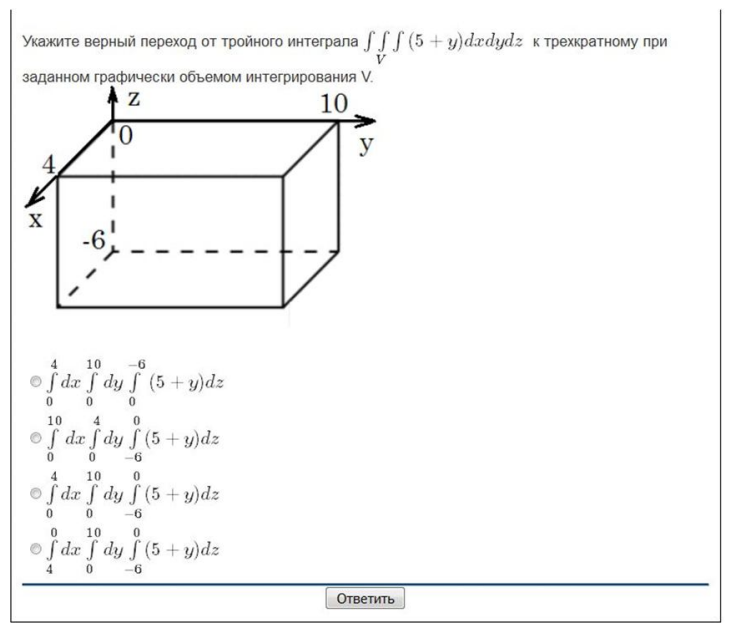

Рис. 5. Вікно тестового завдання за темою «Потрійний інтеграл»

\section{IV Обговорення}

Впровадження в навчальний процес електронного навчального курсу відкриває нові можливості підвищення ефективності навчання. В роботі [16] виділені такі переваги цієї форми навчання як гнучкість і доступність. Так, студенти можуть здобувати освіту у вдалий час і в зручному місці. Вони отримують можливість варіювати час, місце і темп своєї навчальної діяльності, поглиблено вивчати обрані розділи курсу, здійснювати самоконтроль просування по навчальному матеріалу. В тому числі знаходячись поза межами університета. Але, до переваг організації такої форми навчання необхідно віднести ще й економічність, тобто значне скорочення витрат на організацію освітнього процесу. Наприклад, для організації самостійної роботи студента зникає необхідність у великих тиражах друкованої навчально-методичної літератури, тому що матеріали надаються у електронному вигляді.

Впровадження електронних технологій призводить, на думку авторів [17], до зростання технологічності навчання, так як з використанням сучасних програмних і технічних засобів електрона освіта більш ефективна. Крім того, підвищується продуктивність роботи завдяки використання сучасних засобів навчання, нових інструментів і методів навчання, побудови нових моделей навчання. Все це дозволяє більш повно використовувати потенціал навчального контенту. 
Слід відзначити динамічність таких освітніх електронних ресурсів. Нові технології дозволяють побудувати процес освіти на платформі активної взаємодії студента з навчальною системою, а використання мультімедіа технологій стимулює активне навчання. Наочність сучасної фрорми подання навчального матеріалу дозволяє зазирнути всередину досліджуваних процесів за допомогою різних симуляцій. Впровадження такої форми організації роботи несе переваги не тільки для студентів, що вивчають дисципліну, а й для викладача у вигляді нових форм та результатів підзвітності, прозорості та спрощення організації навчального процесу. Так, при використанні електронного навчання відбувається постійне документування навчального процесу. Всі етапи навчальної діяльності студентів і оцінка її результатів відображені на електронних носіях, доступних викладачу. Крім того, навчальна документація доступна всім учасникам навчального процесу, що веде до спрощення організації освітнього процесу. Викладач звільняється від рутинних процесів перевірки виконання індивідуальних завдань, переадресуючи їх системі дистанційного навчання.

На думку авторів [18-19] можна виділити такі особливості пов'язані із змішаною формою навчання: індивідуалізація освітнього процесу; посилення мотивації до навчання; розвиток навичок самостійної роботи, здатності до самоосвіти і саморозвитку; формування самодисципліни і свідомості.

Зростання ролі викладача в освітньому процесі за даною формою навчання ставить декілька викликів перед сучасною педагогічною спільнотою, а саме [20]:

• необхідність підвищення інформаційно-дизайнерської компетентності педагога;

- формування навичок створення специффічних електронних блоків (написання сценаріїв тренажерів; складання тестів різного виду; представлення завдань для спільної роботи студентів тощо);

- вміння роботи користувачем сучасних платформ електронного навчання.

Поряд із перевагами впровадження елементів змішаного навчання у навчальний процес слід відзначити і особливості «зі знаком мінус» та недоліки такої організації навчального процесу. Серед них [21]: необхідність наявності персонального комп'ютера, системи Інтернет, серйозного технічного оснащення навчального процесу; висока трудомісткість розробки електронних курсів; недостатня компетентність розробників і користувачів; недолік відповідних методичних матеріалів.

Основу освітнього процесу при змішаному навчанні становить цілеспрямована, інтенсивна і контрольована самостійна робота студента (освоєння матеріалу, робота в фрорумах і чатах, спілкування по електронній пошті і соціальних мережах). Змішане навчання стимулює вироблення навичок самонавчання і пошуку інформації (необхідність самостійного вивчення матеріалу сприяє розвитку відповідального ставлення до навчання, саме мотивації, планування часу, особистої активності в пошуку інформації, що цікавить). Організація індивідуальної підтримки навчальної діяльності кожного студента викладачем на основі використання онлайн-спілкування та за допомогою отримання зворотного зв'язку від викладача на практиці дозволяє реалізувати індивідуальний підхід. Це можна відзначити як істотну перевагу змішаного навчання в порівнянні з традиційними методами придбання знань «обличчям до обличчя».

Оцінка якості засвоєння навчального матеріалу з використанням автоматизованих систем контролю, що забезпечують тестовий контроль знань з різним рівнем доступу для студентів і викладачів, $€$ обов'язковим спрямуванням реалізації технології змішаного навчання в системі професійної освіти. Форми, методи і засоби змішаного навчання досить тісно взаємодіють між собою. Їх конструктивне поєднання дозволяє забезпечити цілеспрямований характер протікання процесу навчання. Впровадження в освітній процес електронних навчальних ресурсів сприяють засвоєнню змісту і відпрацюванню навчального матеріалу, виконанню контрольних дій, організації самостійної, пошукової, науково-дослідницької, навчальної діяльності студентів, підвищенню їх пізнавального і професійного інтересу.

\section{V Висновки}

Проведене опитування показало, що змішана модель навчання найбільш краща з точки зору студентів. Вона дозволяє вивчати запланований матеріал зі зручною швидкістю, виконувати контролюючі заходи в міру готовності і не обов'язково в аудиторії, мати постійний доступ до навчальнометодичних матеріалів. 
Перехід на змішану модель навчання математичних дисциплін вимагає концептуального підходу в підготовці Web-складової курсу, перевірених експериментально і обгрунтованих психологами навчальних і контролюючих елементів курсу.

До переваг підключення до електронного курсу:

- можливість проведення проблемної лекції в наступному форматі: зміст і основні моменти лекції анонсуються на сайті курсу раніше, ніж час лекції за розкладом (розсилається додаткове повідомлення), що дозволяє студентам заздалегідь самостійно ознайомитися, а викладачеві більш детально розібрати важливий матеріал в аудиторії;

- наявність електронного конспекту лекцій, що дозволяє відсутнім в аудиторії студентам, вчасно зорієнтуватися в розібраному матеріалі; в цілому, студентам легше відновити деталі лекції;

- електронні домашні завдання виявляються зручні перш за все тому, що викладач і студент не прив'язані до часу передачі і перевірки завдання;

- можливість проведення консультації он-лайн;

- можливість використання додаткових інформаційних ресурсів з відео з окремих тем;

- чіткі і відомі заздалегідь критерії оцінювання;

- поліпшення комунікації «викладач - студент», студенти беруть більш активну участь в обговоренні матеріалів курсу.

Таким чином, модель змішаного навчання для курсу вищої математики виправдана, проте вимагає ретельного вибору елементів електронного курсу та відстеження їх ефективності в навчанні. Окрему увагу слід приділити вибору додаткових електронних ресурсів. В цілому, змішаний підхід до навчання дає більше інтерактивності і стимулює активне навчання, мотивує студентів до навчальнопізнавальної діяльності, дозволяє сфрормувати навички самостійного навчання, сприяє розвитку творчого мислення та пошуку нестандартних рішень. Студенти стають активними ініціаторами своєї самостійної навчальної діяльності, в результаті чого підвищується їх самосвідомість і самооцінка, виникає стимул до подальшої роботи і досліджень. Можливості змішаного навчання дозволяють розширити психологічну компоненту мотивації навчання, забезпечити оволодіння способами виконання інформаційно-аналітичної діяльності в рамках процесу навчання, отримання знань за обраною професією.

\section{Бібліографічні посилання}

1. Опанасюк Ю. Дистанційне навчання як наслідок еволюції традиційної системи освіти / Вища освіта України, 2016. 1. С. 49-53. URL: http://nbuv.gov.ua/UJRN/vou_2016_1_10. (дата звернення 15.02.2020).

2. Al-Qahtani A. A., Higgins S. E. Effects of traditional, blended and e-learning on students' achievement in higher education / Journal of Computer Assisted Learning, 2013. 29(3), P. 220-234. doi: 10.1111/j.1365-2729.2012.00490.x

3. Половая Н. О. Дистанційне навчання як інноваційна форма освіти / Грані, 2017. Т. 20, 1. С. 27-31. doi: 10.15421/17174

4. Ставицька І. В. Моделі дистанційного навчання / Новітні освітні технології : зб. тез Х міжнар. наук.-практ. конф., 14 січня 2015. URL: http://confesp.fl.kpi.ua/ru/node/1151 (дата звернення: 16.02.2020).

5. Ya-Wen Lin, Chih-Lung Tseng, Po-Jui Chiang The Effect of Blended Learning in Mathematics Course / EURASIA Journal of Mathematics Science and Technology Education, 2017. 13(3). P.741-770. doi: 10.12973/eurasia.2017.00641a

6. Moe C. E., Rye S. A. Blended learning: Communication, locations and work-life practices / Educational Media International, 2011. 48(3). P.165-178. doi:10.1080/09523987.2011.607320

7. Lothridge K., Fox J., Fynan E. Blended learning: Efficient, timely and cost effective / Australian Journal of Forensic Sciences, 2013. 45(4). P.407-416. doi:10.1080/00450618.2013.767375

8. Zhonggen $Y$. Blended learning over two decades / International Journal of Information and Communication Technology Education, 2015. №11(3). P. 1-19. doi:10.4018/IJICTE.2015070101

9. Anderman E. M., Gimbert B., O'Connell A. A., Riegel L. Approaches to academic growth assessment / British Journal of Educational Psychology, 2015. 85(2). P.138-153. doi:10.1111/bjep.12053

10. Галецький С., Галецька Т. Дистанційне навчання як елемент інформаційно-комунікаційних технологій в освіті / Збірник наукових праць Уманського державного педагогічного університету імені Павла Тичини, 2018. Вип. 1. C. 54-62. URL: http://nbuv.gov.ua/UJRN/znpudpu_2018_1_8 (дата звернення: 15.02.2020).

11. Altunoglu A. Initial perceptions of open higher education students with learner management systems / Turkish Online Journal of Distance Education (TOJDE), 2017. 18 (3). P. 96-104. doi: https://doi.org/10.17718/tojde.328939

12. Wai C., Seng E. Measuring the effectiveness of blended learning environment: A case study in Malaysia / Education and Information Technologies, 2015. 20(3). P. 429-443. doi:10.1007/s10639-013-9293-5 
13. Овсяннікова В. В. Дистанційне навчання в освітньому процесі вищого навчального закладу / Вісник Запорізького національного університету. Педагогічні науки, 2016. 2. С. 56-60. URL: http://nbuv.gov.ua/UJRN/Vznu_ped_2016_2_10 (дата звернення: 16.02.2020).

14. Бублик В. В. Шляхами дистанційної освіти та електронного навчання. Наукові записки НаУКМА. Комп'ютерні науки, 2018. T. 1. C. 4-9. doi: https://doi.org/10.18523/2617-3808.2018.4-9

15. Almasaeid T. F. The effect of using blended learning strategy on achievement and attitudes in teaching science among 9th grade students / European Scientific Journal, 2014. 10(31). P. 133-145. URL: https://eujournal.org/index.php/esj/article/view/4573/4370

16. Кадемія М. Ю., Уманець В. О. Дистанційне навчання у віртуальному університеті як спосіб доступу до якісної освіти / Відкрите освітне е-середовище сучасного університету, 2016. Вип. 2. С. 175-184. URL: http://nbuv.gov.ua/UJRN/oeeemu_2016_2_15 (дата звернення: 15.02.2020).

17. Журавська Н. С. Дистанційне навчання в країнах Європейського Союзу та Україні: реалії та перспективи / Науковий вісник Національного університету біоресурсів і природокористування України. Серія: Педагогіка, психологія, філософія, 2016. Вип. 233. С. 101-106. URL: http://nbuv.gov.ua/UJRN/nvnau_ped_2016_233_17 (дата звернення: 15.02.2020).

18. Ключко С. С., Євтушенко В. М., Сирцов В. К. Сучасний освітній процес: курс на дистанційне навчання / Morphologia, 2017. T. 11, № 2. C. 58-60. URL: http://nbuv.gov.ua/UJRN/Morphology_2017_11_2_12 (дата звернення: 15.02.2020).

19. Barak M. Science teacher education in the twenty-first century: A pedagogical framework for technology-integrated social constructivism / Research in Science Education, 2017. 47 (2). P. 283-303. doi:https://dx.doi.org/10.1007/s11165-015-9501-y

20. Муращенко Т. В. Змішане та дистанційне навчання як спосіб доступу до якісної освіти / Відкрите освітнє е-середовище сучасного університету, 2017. Вип. 3. URL: http://nbuv.gov.ua/UJRN/oeeemu_2017_3_45 (дата звернення: 16.02.2020).

21. Ляхоцька Л. Дистанційне навчання як педагогічна технологія неперервної освіти / Педагогічні науки. 2014. Вип. 61-62. С. 33-39. URL: http://dspace.pnpu.edu.ua/bitstream/123456789/3504/1/Liakhotska.pdf (дата звернення: 15.02.2020).

\section{References}

1. Opanasyuk, Yu. (2016), Distancijne navchannya yak naslidok evolyuciyi tradicijnoyi sistemi osviti // Visha osvita Ukrayini, 1, 49-53. URL: http://nbuv.gov.ua/UJRN/vou_2016_1_10. (data zvernennya 15.02.2020). [in Ukrainian]

2. Al-Qahtani, A. A., Higgins, S. E. (2013) Effects of traditional, blended and e-learning on students' achievement in higher education // Journal of Computer Assisted Learning, 29(3), 220-234. doi: 10.1111/j.1365-2729.2012.00490.x

3. Polovaya, N. O. (2017) Distancijne navchannya yak innovacijna forma osviti // Grani, 20, 27-31. doi: 10.15421/17174 [in Ukrainian].

4. Stavicka, I. V. (2015) Modeli distancijnogo navchannya // Novitni osvitni tehnologiyi : zb. tez H mizhnar. nauk.-prakt. konf., 14 sichnya. URL: http://confesp.fl.kpi.ua/ru/node/1151 (data zvernennya: 16.02.2020). [in Ukrainian]

5. Ya-Wen, Lin, Chih-Lung, Tseng, Po-Jui, Chiang (2017) The Effect of Blended Learning in Mathematics Course // EURASIA Journal of Mathematics Science and Technology Education, 13(3), 741-770. doi: 10.12973/eurasia.2017.00641a

6. Moe, C. E., Rye, S. A. (2011) Blended learning: Communication, locations and work-life practices // Educational Media International, 48(3), 165-178. doi:10.1080/09523987.2011.607320

7. Lothridge, K., Fox, J., Fynan, E. (2013) Blended learning: Efficient, timely and cost effective // Australian Journal of Forensic Sciences, 45(4), 407-416. doi:10.1080/00450618.2013.767375

8. Zhonggen, Y. (2015) Blended learning over two decades // International Journal of Information and Communication Technology Education, 11(3), 1-19. doi:10.4018/IJICTE.2015070101

9. Anderman, E. M., Gimbert, B., O'Connell, A. A., Riegel, L. (2015) Approaches to academic growth assessment // British Journal of Educational Psychology, 85(2), 138-153. doi:10.1111/bjep.12053

10. Galeckij, S., Galecka, T. (2018) Distancijne navchannya yak element informacijno-komunikacijnih tehnologij v osviti // Zbirnik naukovih prac Umanskogo derzhavnogo pedagogichnogo universitetu imeni Pavla Tichini, 1, 54-62. URL: http://nbuv.gov.ua/UJRN/znpudpu_2018_1_8 (data zvernennya: 15.02.2020). [in Ukrainian]

11. Altunoglu, A. (2017) Initial perceptions of open higher education students with learner management systems // Turkish Online Journal of Distance Education (TOJDE), 18 (3), 96-104. doi: https://doi.org/10.17718/tojde.328939

12. Wai, C., Seng, E. (2015) Measuring the effectiveness of blended learning environment: A case study in Malaysia // Education and Information Technologies, 20(3), 429-443. doi:10.1007/s10639-013-9293-5

13. Ovsyannikova, V. V. (2016) Distancijne navchannya v osvitnomu procesi vishogo navchalnogo zakladu // Visnik Zaporizkogo nacionalnogo universitetu. Pedagogichni nauki, 2, 56-60. URL: http://nbuv.gov.ua/UJRN/Vznu_ped_2016_2_10 (data zvernennya: 16.02.2020). [in Ukrainian]

14. Bublik, V. V. (2018) Shlyahami distancijnoyi osviti ta elektronnogo navchannya // Naukovi zapiski NaUKMA. Komp'yuterni nauki, 1, 4-9. doi: https://doi.org/10.18523/2617-3808.2018.4-9 [in Ukrainian]

15. Almasaeid, T. F. (2014) The effect of using blended learning strategy on achievement and attitudes in teaching science among 9th grade students // European Scientific Journal, 10(31), 133-145. URL: https://eujournal.org/index.php/esj/article/view/4573/4370

16. Kademiya, M. Yu., Umanec, V. O. (2016) Distancijne navchannya u virtualnomu universiteti yak sposib dostupu do yakisnoyi osviti II Vidkrite osvitnye e-seredovishe suchasnogo universitetu, 2, 75-184. URL: http://nbuv.gov.ua/UJRN/oeeemu_2016_2_15 (data zvernennya: 15.02.2020). [in Ukrainian] 
17. Zhuravska, N. S. (2016) Distancijne navchannya v krayinah Yevropejskogo Soyuzu ta Ukrayini: realiyi ta perspektivi // Naukovij visnik Nacionalnogo universitetu bioresursiv i prirodokoristuvannya Ukrayini. Seriya: Pedagogika, psihologiya, filosofiya, 233, 101-106. URL: http://nbuv.gov.ua/UJRN/nvnau_ped_2016_233_17 (data zvernennya: 15.02.2020). [in Ukrainian]

18. Klyuchko, S. S., Yevtushenko, V. M., Sircov, V. K. (2017) Suchasnij osvitnij proces: kurs na distancijne navchannya /I Morphologia, 11 (2), 58-60. URL: http://nbuv.gov.ua/UJRN/Morphology_2017_11_2_12 (data zvernennya: 15.02.2020). [in Ukrainian]

19. Barak, M. (2017) Science teacher education in the twenty-first century: A pedagogical framework for technology-integrated social constructivism // Research in Science Education, 47 (2), 283-303. doi:https://dx.doi.org/10.1007/s11165-015-9501-y

20. Murashenko, T. V. (2017) Zmishane ta distancijne navchannya yak sposib dostupu do yakisnoyi osviti // Vidkrite osvitnye eseredovishe suchasnogo universitetu, 3. URL: http://nbuv.gov.ua/UJRN/oeeemu_2017_3_45 (data zvernennya: 16.02.2020). [in Ukrainian]

21. Lyahocka, L. (2014) Distancijne navchannya yak pedagogichna tehnologiya neperervnoyi osviti // Pedagogichni nauki, 61-62, 33-39. URL: http://dspace.pnpu.edu.ua/bitstream/123456789/3504/1/Liakhotska.pdf (data zvernennya: 15.02.2020). [in Ukrainian]

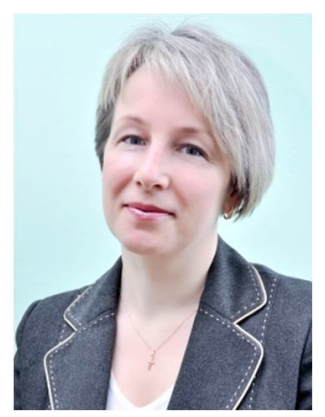

Білоус Олена Анатоліївна,

к.ф.-м.Н., доцент кафедри математичного аналізу і методів оптимізації,

Сумський державний університет,

вул. Р.- Корсакова 2, м. Суми, Україна, 40007,

Тел. +38(05426) 8-77-58 . E-mail: o.bilous@maimo.sumdu.edu.ua

Bilous Olena Anatolievna,

Ph.D. Sciences, associate professor of mathematical analysis and optimization methods,

Sumy State University,

st. R.- Korsakov 2, Sumy, 40007, Ukraine.

Tel. +38(05426) 8-77-58 . E-mail: o.bilous@maimo.sumdu.edu.ua

ORCID: 0000-0003-2288-4030

\section{Citation (APA):}

Bilous, O. (2020). Implementation of the blended learning model in the study of mathematical disciplines. Engineering and

Educational Technologies, 8 (1), 8-18. doi: https://doi.org/10.30929/2307-9770.2020.08.01.01

Цитування (ДСТУ 8302:2015):

Білоус О. А. Впровадження моделі змішаного навчання при вивченні математичних дисциплін / Інженерні та освітні технологіï. 2020. Т. 8. № 1. С. 8-18. doi: https://doi.org/10.30929/2307-9770.2020.08.01.01

Обсяг статmі: $\quad$ сторінок - 11 ; умовних друк. аркушів - $1,593$. 